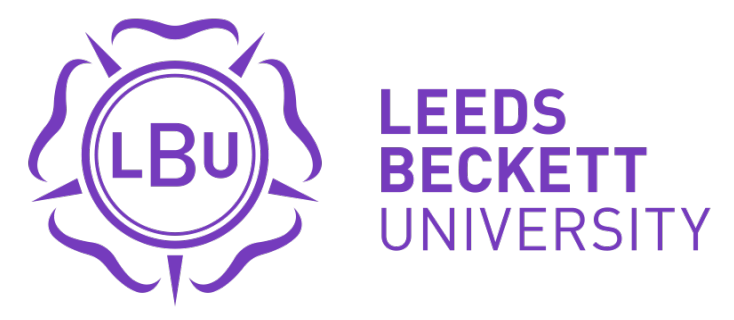

Citation:

Cutts, D and Webber, D and Widdop, P and Johnston, R and Pattie, C (2014) With a little help from my neighbours: A spatial analysis ofthe impact of local campaigns at the 2010 British general election. Electoral Studies, 34. 216 - 231. ISSN 0261-3794 DOI: https://doi.org/10.1016/j.electstud.2013.12.001

Link to Leeds Beckett Repository record:

https://eprints.leedsbeckett.ac.uk/id/eprint/1309/

Document Version:

Article (Accepted Version)

The aim of the Leeds Beckett Repository is to provide open access to our research, as required by funder policies and permitted by publishers and copyright law.

The Leeds Beckett repository holds a wide range of publications, each of which has been checked for copyright and the relevant embargo period has been applied by the Research Services team.

We operate on a standard take-down policy. If you are the author or publisher of an output and you would like it removed from the repository, please contact us and we will investigate on a case-by-case basis.

Each thesis in the repository has been cleared where necessary by the author for third party copyright. If you would like a thesis to be removed from the repository or believe there is an issue with copyright, please contact us on openaccess@leedsbeckett.ac.uk and we will investigate on a case-by-case basis. 


\title{
With a little help from my neighbours: a spatial analysis of the impact of local campaigns at the 2010 British general election
}

\author{
David Cutts, Donald Webber, Paul Widdopc, Ron Johnston, and Charles Pattie
}

Published: 2014, Electoral Studies, 34, 216-231.

\section{Introduction}

There is growing empirical evidence to support the proposition that there are spatial patterns of voting in Britain over and above those that reflect compositional effects similar people do not necessarily vote in the same way wherever they live (Johnston and Pattie, 2006; Cutts and Webber, 2010). Central to this claim is the observation that voting is a learned activity which takes place in a variety of contexts and through a range of mechanisms at several spatial scales (Cox, 1969; Agnew, 1987; Taylor and Johnston, 1979; Johnston and Pattie, 2006). Voters are influenced by the contexts within which they find themselves, and these contextual effects complement the compositional effects representing individual characteristics such as social class, and derive from a variety of sources, including individuals interacting with their material environment, with their social networks, and/or with political parties through placespecific campaigning.

The nature and impact of constituency party campaigning in British general elections has been the subject of much research over recent decades. One group of scholars has used data from candidates' agents to show that intensive campaign effort yields a greater electoral payoff (Denver and Hands, 1997), findings that are broadly consistent with studies conducted since the 1970s using the amounts that a candidate spent as a surrogate measure of campaign intensity (Johnston and Pattie, 1995; Pattie and Johnston, 2009). Local party spending does not win votes directly, but it facilitates the canvassing and mobilisation of supporters and the follow-up targeting of key voters as well as meeting the costs of leaflets, posters and other campaign literature.

British elections are won or lost in key battleground seats - the marginal seats - where party activity is at its most intense. Reflecting this, not only have local campaigns become more professional and centralised (Fisher et al, 2006), but circumstantial evidence suggests that candidates are active in canvassing support and building up their local profiles well before the election campaign begins, especially in marginal constituencies and/or target seats (Cutts et al, 2012; Fisher and Denver, 2008; Cutts, 2006a; 2006b; Johnston and Pattie, 2010). Local campaigning has also become highly visible through the increasing use of posters displaying the local candidates' name, street stalls in town centres and local shopping precincts, as well as party workers out 'flying the flag' - wearing party badges and other merchandise while canvassing or leafleting. This enhanced public profile of campaigns in target seats led Cutts and Webber (2010) to speculate that there may be positive spillover effects from intensive party activity from one Parliamentary constituency to its neighbours (see also Johnston and Pattie, 2008). By explicitly taking account of spatial effects in the modelling process, they identified evidence that the more a party spends on campaigning in constituencies adjacent to another, the better its performance in the latter. A drawback of that study was that, because of the limited data available, it only analysed spending on the 'official' or short campaign, the few 
weeks between the election being called and polling day. However, this is problematic, as parties can be engaged in activities to raise their local profiles in key constituencies many months before the election occurs. Both the direct campaign effect and the spillover to surrounding seats may well be influenced by this longerterm local campaign effort, which previous studies have been unable to capture. That said, a potential solution is now available. For the 2010 general election, legal restrictions on campaign spending also covers the so-called long campaign (the last four months before the election is called) as well as the short campaign (Johnston et al., 2011, 2012).

Party campaigning occurs in places, making it unsurprising that there is an increasing amount of empirical evidence supporting the proposition that spatial variations in voting patterns exist (Johnston and Pattie, 2006; Johnston et al, 2007) and that spatial heterogeneity and autocorrelation should be considered when attempting to examine the drivers of political support (Cutts and Webber, 2010). The presence of spatial autocorrelation in a data set can indicate a number of issues that may confound its analysis. For example, positive autocorrelation in regression residuals may indicate that the model is under-specified - the spatial clustering of positive values suggesting other variables that should be included (such as the percentage employed in agriculture if positive residuals are clustered in rural areas). Alternatively, it may indicate the presence of spillover effects across neighbouring constituencies: factors which influence support for a party in one constituency could have an impact on voters living in adjacent seats - because they are aware (perhaps through travel there) of the intensity of the campaign in the neighbouring seats and are influenced by that activity in their voting decisions. This latter spatial process - of diffusion, spread or, as we prefer here, spillover - is likely to operate with regard to local campaigns: a party's intense campaign in one place (indexed by the amount spent on it) could influence not only its support there but also in neighbouring places. The effect of campaigning in neighbouring seats is often interpreted as a positive spillover effect, but it is probable that it also has a negative effect too. The harder a party campaigns in the seats neighbouring yours, the more your opponents' local resources are tied down responding to this increase in spending, and the more difficulty they'll have in justifying the redirection of those finite resources to your seat, which would make it marginally easier for you to capture the seat.

In addition, spatial autocorrelation in the geography of the dependent variable may indicate a technical problem regarding the selection of areas for analysis. In Britain there are blocks of constituencies where one party performs much better than elsewhere because of an underlying geography of factors influencing voter choice such as the geography of social class. If those blocks of constituencies are unequal in size, then the relative impact of each constituency on the overall regression model will vary, and as a consequence the standard errors will be under-estimated and/or the population of observations unequally weighted. To eliminate that potential problem, spatial error models introducing lag effects for the dependent variable are used to remove the autocorrelation. Both spillover and spatial lag effects are explored in the current paper.

In the next section we stress the importance of geography on voting in British elections and examine reasons why space should be taken into account in its modelling. Section 3 outlines key hypotheses to be tested, the modelling approach and 
the explanatory variables to be used. Section 4 presents an exploratory spatial analysis to illustrate the geographical element to party vote shares and party spending patterns across Britain and reiterates the need to take account of spatial heterogeneity when examining patterns of party support. Econometric estimations are presented in Section 5 which show that local party activism during both the long and short campaign matters, before testing hypotheses regarding the presence of spillover effected - that parties obtain a greater electoral payoff in a constituency if they run intensive, highly visible campaigns not only there but also in constituencies adjacent to that constituency. Our final model tests whether these findings hold after taking account of spatial autocorrelation in the dependent variable.

\section{The Geography of Voting in Great Britain}

There is a growing empirical literature which emphasises the existence and intensity of spatial variations in vote shares. Early studies provided circumstantial evidence that similar people vote differently in different types of places (Cox, 1969; Crewe and Payne, 1971) while others put forward arguments consistent with the neighbourhood effects thesis (Butler and Stokes, 1969; 1974); the spatial polarisation of party support exceeded what might be expected given the socio-demographic polarisation of the population (Miller, 1977; 1978). This is often attributed to the idea that 'people who talk together, vote together' (Miller, 1978), especially people in the same kinship networks (Pattie and Johnston, 2000). Early criticisms mainly focussed on the apparent lack of evidence of how such processes operated (Dunleavy, 1979) even though subsequent analyses during the 1980s clearly showed that sociodemographic composition could not account for party support at the constituency level (Johnston et al, 1988). Later studies have generally upheld the existence of neighbourhood effects in British elections (Heath and Andersen, 2002; Pattie and Johnston, 2000). For instance, use of 'bespoke neighbourhoods' ${ }^{1}$ not only provided evidence of small scale, individual level spatial variations in voting (Johnston et al., 2004; 2007) but also found that people from similar social backgrounds voted differently depending on their local context. Such neighbourhood effects apparently operated at a variety of scales nesting within each other (Johnston and Pattie, 2006); people were found to follow similar patterns of political behaviour where they lived in close proximity, interacted with others, shared day-to-day experiences, and belonged to the same social networks (Johnston et al, 2005; Books and Prysby, 1991; 1999; Huckfeldt and Sprague, 1995).

Other important studies of inter-constituency variations in party support have focused on the impact of party activism (Denver and Hands, 1997; Pattie and Johnston, 2009; Fieldhouse and Cutts, 2009). Local electioneering has now become a vital part of contemporary general election campaigns. At the constituency level, parties focus efforts on key marginal seats, targeting key voters both prior to and during the election campaign. Three different groups of scholars, using different measures of campaign strength, have regularly demonstrated the electoral benefits of intense local campaigns in the UK (Denver and Hands, 1997; Pattie et al., 1995; Whiteley and Seyd, 1994), while one team has recently combined these measurements

\footnotetext{
${ }^{1}$ See Johnston and Pattie (2006) for a detailed explanation of how bespoke neighbourhoods are constructed and an overview of their use in a number of recent studies.
} 
of campaign effort and confirmed that, other things being equal, the more actively a party campaigns in a seat the more votes it wins and the fewer votes its opponents get (Fieldhouse and Cutts, 2009): parties often benefit more when they are challenging than when they are the incumbent party in the constituency (Pattie and Johnston, 2009). There is also growing evidence that parties through highly developed local targeting strategies and grassroots local activism, party organisations now successfully operate at spatial scales below the constituency level in order to maximise their potential electoral rewards (Cutts, 2006a; 2006b).

A recent analysis of campaigning at the 2005 general election identified potential positive spillover effects in party support in constituencies contiguous to those where there was intense party activism: vote shares in constituency $i$ were strongly influenced by highly visible campaigning in $i$ 's neighbouring constituencies. (Cutts and Webber, 2010). Such non-independence may be due to, amongst other things, feedback forces, ${ }^{2}$ as well as grouping forces (Voss et al, 2006; Anselin, 2001; Wrigley et al, 1996). ${ }^{3}$ The assumption that geographically contiguous parliamentary constituencies with similar party vote shares might be influenced by grouping forces, such as intense party activism, is not entirely new, however. Previous work had found that the Liberal Democrats improved their local election support following intensive activism in areas surrounding those where they won at the previous contest (Dorling, Rallings and Thrasher, 1998). Despite evidence of a spatial dimension to the Liberal Democrat vote, albeit at the local election level, the findings were largely circumstantial, however, and were not based on spatial econometric modelling techniques to take account of possible spatial autocorrelation in the residuals. But these findings did suggest that where parties (Liberal Democrats in this case) spent relatively high amounts on campaigning in one local area, they could reap electoral rewards from spatially autocorrelated influences if large amounts were also spent in contiguous areas. This argument was tested using spatial regression techniques by Cutts and Webber (2010). Their findings were conclusive: constituencies were not spatially independent, with campaign spillover effects having a positive influence on party performance, particularly in the case of the Liberal Democrats. Given this, we expect that vote shares in constituency $i$ will be influenced by intense party activism during both the long and the short campaign in $i$ 's neighbouring constituencies. Spatial econometric techniques are therefore used here to assess whether there was any spillover effects of party activity, during both campaign periods, at the constituency level in the 2010 general election.

\footnotetext{
${ }^{2}$ Feedback forces are likely to be particularly evident at the smaller the spatial scale because of the higher likelihood and frequency of contact between voters (Voss et al, 2006). Where the impression of a political party is positive, then this is likely to be shared with friends and neighbours within the area and within contiguous areas who interact most with these voters. According to agent interaction theory, one might expect some spillover effects with a positive correlation in political party vote shares between contiguous parliamentary constituencies (Irwin and Bockstael, 2004). This is one potential source of spatial autocorrelation but it is not the primary focus of this paper.

${ }^{3}$ Grouping forces are where individuals with shared characteristics are found clustered together by choice or they are constrained to co-locate by social, political or economic forces e.g. individuals in poverty subject to the operation of the local labour market. It is also important to note that spatial nonindependence may be present but the processes creating the outcome might not themselves be intrinsically spatial. See the following literature for a more detailed overview of why autocorrelated residuals occur (Voss et al, 2006; Anselin, 2001).
} 


\section{The 2010 General Election: The Changing Electoral Context}

For the first time in thirteen years, Labour was widely expected to lose the 2010 general election. Following the 2005 general election, the party fell behind the Conservatives in the opinion polls and experienced heavy losses in both local elections and the 2009 European election during the electoral cycle. While Labour adopted an almost entirely defensive electoral strategy at the constituency level (Johnston et al., 2011, 2012), the Conservatives targeted a substantial number of key seats where they lost in 2005 up to three years in advance of the 2010 general election (Ashcroft, 2010; Johnston and Pattie, 2010). Although they expected to win the election, whether they would gain an overall majority in the House of Commons was much less certain. The party needed to gain 116 seats to form the next government, which required one of the largest UK election swings in its favour since 1945. The Liberal Democrats had polled solidly around the $20 \%$ mark since 2005 and hoped to benefit from disillusionment with Labour in its northern heartlands. Much less certain was how they would fare against a resurgent Conservative party in the South, particularly in those seats the Liberal Democrats were defending with relatively small margins; the retirement of popular Liberal Democrat local incumbents further threatened to lead to Conservative gains at their expense. While each party integrated its national and local campaigns, intensive activism was focused on their key target seats. Despite the changing electoral context from five years previously, did intensive party campaigning matter? Was it effective in the months leading up to the 'official campaign'? And were there any positive spillover effects from party campaign effort in 2010: were the vote shares in constituency $i$ influenced by highly visible party activism both over short and long campaign in $i$ 's neighbouring constituencies?

To examine the impact of local party campaigning on party support in 2010 we employ linear regression models. Here we use candidate campaign spending as the measure of campaign intensity. This has two main advantages. First, a number of studies have stressed the validity and reliability of party spending as a surrogate measure given that it correlates strongly with individual contact data aggregated from the British Electoral Study surveys and survey information directly from individuals (party agents) who organise their party's election campaign (Denver and Hands, 1997; Johnston and Pattie, 1995, 2006). Second, political parties are legally required to make returns of their election expenses to the Electoral Commission which has made them publicly available, thus ensuring near universal coverage with spending records for each party standing in every seat at the 2010 general election, although our analyses here are restricted to the three largest British parties that fought all but one of the constituencies in 2010 (the exception was that defended by the Speaker).

Candidate spending is legally capped. The size of that cap varies from constituency to constituency, and is affected by two factors: the constituency electorate (larger electorates generate higher caps than smaller ones); and whether the constituency is a borough (more urban) or county (more rural) seat, on the grounds that, other things being equal, the costs of campaigning are higher in the latter than in the former, due to the lower population densities and greater travel costs in rural rather than urban areas. It is therefore sensible (as in other studies using these data) to standardise this measure by calculating a candidate's spending as a percentage of the legal maximum permitted in the constituency (Johnston and Pattie, 1995; Pattie and 
Johnston, 2009). While party candidates continued to be legally restricted in the amount that the could spend for the short campaign, ${ }^{4}$ new legislation came into force before the 2010 general election which placed additional restrictions on what they could spend for a longer period of time. During the long campaign candidates were allowed to spend nearly two and half times as much as the legal expenditure limit for the 'official or short campaign period (Johnston et al, 2011, 2012). ${ }^{5}$ We analyse party candidate spending during the short and long campaign separately, with the short campaign variable orthogonalised to remove any potential collinearity problems between the two variables. ${ }^{6}$

Our models also include social cleavage variables indicating the socioeconomic and demographic characteristics of the constituency populations (derived from the 2001 census). These are not only relatively stable and exogenous but have long been established as important determinants of voting for Labour and the Conservatives because those parties tend to do better or worse in areas depending on the types of people who live there (Cutts, 2006). The situation is somewhat different for the Liberal Democrats, however (Curtice, 1996). While there is some evidence that Liberal Democrat voters tend to be more middle class than average, have degrees, and work in the public sector (Russell and Fieldhouse, 2005), the party (unlike the other main parties) lacks a natural support base and its areas of relative strength in general reflect long periods of developing a local party organisation and support, with success in local government elections providing the foundations for Parliamentary campaigns. We use eight variables taken from the 2001 census which have been used in numerous constituency level analyses to examine voting patterns at recent general elections (Johnston et al, 1998; Fieldhouse et al, 2006; Cutts and Webber, 2010).

In 2010, Labour was expected to lose some support in student areas given the Liberal Democrats' opposition to university tuition fees and their efforts to target younger voters (Cutts, 2012). While the Liberal Democrats had improved their performance in 2005 in those areas, at Labour's expense, they didn't manage to make the gains expected in constituencies with large Muslim electorates. In 2010, opposition to the War in Afghanistan had replaced the War in Iraq as a salient issue (opposition to which had gained the Liberal Democrats considerable support in 2005). In an attempt to appeal to the hard fought-for Muslim vote, the Liberal Democrats often reminded electors of their Anti-Iraq war stance in order to maximise support in those seats with a high proportion of Muslim voters. Three of the census variables (the percentages of Muslims, students and people working in education) were selected

\footnotetext{
${ }^{4}$ The short campaign begins either on the day after Parliament is dissolved (15 April in 2010) or, if later, when a party's candidate is formally adopted, and ending on election day (6 May, 2010). For the 2010 election, each candidate could spend a fixed sum of $£ 7,150$ plus an additional $7 \mathrm{p}$ per registered elector in rural seats and 5p per registered elector in urban constituencies (Johnston et al, 2012).

${ }^{5}$ If a Parliament runs for its full term, the long campaign period is between the end of the $55^{\text {th }}$ month after a Parliament first sat and the date when Parliament is dissolved the maximum a candidate can spend is a fixed sum of $£ 25,000$ plus, as in the short campaign, $7 p$ and $5 p$ per registered elector in rural and urban constituencies respectively.

${ }^{6}$ We decided to orthogonalise candidate spending during the short campaign period because of potential collinearity issues with the long campaign variable. For instance, the correlation between 'long' and 'short' campaign spending for the Conservatives, Labour and the Liberal Democrats was $0.627^{* *}, 0.589^{* *}$ and $0.741^{* *}$ respectively. The second variable is thus the residual amount spent then from a regression of the party's short campaign spending on its long campaign total.
} 
to explore whether the Liberal Democrats performed better in areas where those groups comprised a relatively large share of the local population; the other five (the percentages with degrees, working in either manufacturing or agriculture, homeowners, and pensioners) were selected to represent the long-established social cleavages that should discriminate between support for Labour and the Conservatives.

\section{Exploratory Spatial Data Analysis: The 2010 General Election}

A series of exploratory tests were conducted to examine spatial patterning in the geography of voting at the 2010 general election. Moran's I is a measure of global spatial autocorrelation or overall clustering in a dataset, providing a formal indication of the extent of linear association between a vector of standardised observed values and a weighted average of standardised values for neighbouring observations (in this case constituencies). The type and strength of spatial autocorrelation is commonly visualised in a Moran scatter plot where the slope of the regression line corresponds to the I value (Anselin, 1996), the extent to which support for each political party in each constituency is correlated with that party's share in contiguous constituencies.

In each Moran's I scatter plot for voting patterns (Figure 1), the relevant party's standardised vote share in 2010 in a constituency is on the $\mathrm{x}$-axis and the y-axis shows the standardised value of its average vote share in neighbouring constituencies as defined by a queen contiguity weights matrix (i.e. all constituencies with which it has a common boundary). ${ }^{7}$ The four quadrants on the scatter-plot indicate different types of local association. The upper right (high-high) and bottom left (low-low) quadrants depict positive spatial association. The former in Figure 1 contains those constituencies with above average party support which share boundaries with neighbouring parliamentary constituencies that also have above average values of the same party's vote share. The latter incorporates those constituencies with party support below the mean with neighbouring parliamentary constituencies also with below average values. By contrast, the upper left (low-high) and bottom right (highlow) quadrants depict negative spatial association; the former contains constituencies with below average vote shares surrounded by parliamentary constituencies that have party support above the mean, while the latter depicts the opposite.

Insert Figure 1a-1c

Figures 1a-1c indicate the spatial autocorrelation in the 2010 voting patterns: the Moran's I statistics are positive and statistically significant with values of $0.31,0.66$ and 0.64 for the Liberal Democrats, Conservatives and Labour parties respectively; the degree of spatial autocorrelation is thus strongest for the latter two parties, indicating that there is greater spatial clustering of party performance across constituencies for the Conservative and Labour parties. The Liberal Democrats'

\footnotetext{
${ }^{7}$ Given that the data are standardised, the units on the scatter plot are expressed in standard deviations from the mean.
} 
support is closer to a random distribution - that this is much more localised is indicated by the greater dispersion of values in the high-high quadrant in Figure 1a than in Figures $1 \mathrm{~b}-1 \mathrm{c}$ and the intensity of values in the low-low quadrant, which suggests that there are substantial tracts of neighbouring constituencies where the Liberal Democrats obtained relatively small shares of the votes cast.

Was the pattern of spending by each party also spatially correlated, with constituencies with relatively high levels clustered alongside others with similarly high values? Figures $2 \mathrm{a}-2 \mathrm{c}$ are scatter-plots for spending on the long campaign; the $\mathrm{x}$ axes show the party's expenditure in the constituency and the y-axes its average expenditure in the adjacent constituencies. ${ }^{8}$ They indicate some clustering especially in the low-low quadrant (parts of the country where a party spent below the average in most constituencies - but the slope coefficients are much smaller than for the pattern of voting: $0.13,0.15$ and 0.10 for the Liberal Democrats, Conservatives and Labour respectively. There was much greater spatial clustering in spending on the short campaign, however (Figures 3a-3c), especially for the Conservatives ( $\mathrm{I}=0.30$ ) and Labour (0.28); the coefficient for the Liberal Democrats was considerably smaller (0.20), reflecting the greater scatter of points in Figure $3 c .{ }^{9}$ In each case, alongside the clustering of constituencies in the low-low quadrant indicating parts of the country where there was little spending in neighbouring constituencies there was also a large number of observations in the high-high quadrant (relative to the small numbers in the other two quadrants where there was no clustering of constituencies with similar spending levels).

\author{
Insert Figures 2a-2c \\ Insert Figures 3a-3c
}

In general, therefore, the pattern of spending by each of the parties during both of the campaign periods was non-random: each party tended to spend above average amounts in neighbouring constituencies in some parts of the country and below average in clusters elsewhere. Maps of the distribution of seats in the four quadrants (termed LISA - Local Indicators of Spatial Association - maps) indicate where those clusters are present (Figures 4-9).

\title{
Insert Figures 4-5
}

For the Liberal Democrats, Figures 4 and 5 identify clusters of constituencies where spending was at relatively high levels for both campaigns - notably in one of

\footnotetext{
${ }^{8}$ There is likely to be some skewness in these figures given that the parties did not spend any money (some zero entries) in a number of constituencies during the long campaign.

${ }^{9}$ Here we use the 'raw' short campaign spending data. The orthogonalised short campaign variables are used in the statistical models.
} 
its major electoral heartlands of the Southwest and Southwest London (Twickenham, Richmond Park), especially for the short campaign, and in parts of the Southeast around Southampton and Portsmouth (where the party has held several seats at recent elections). There were also clusters of high spending during the short campaign in other parts of London notably in South London near Bermondsey, Camberwell and Peckham, and moving northwards in the two Islington constituencies and a number of neighbouring seats. Clusters of constituencies where spending was below average were in parts of urban England (notably Greater Manchester and Merseyside) plus Scotland's central belt and in the eastern parts of London. Over most of the rest of the country there is no significant pattern.

\section{Insert Figures 6-7}

Comparable patterns are shown for Conservative spending. During the long campaign (Figure 6), there were clusters of above average spending in the Southwest of England and Southwest parts of London (Richmond Park, Wimbledon, Putney etc), and of below average spending in the major urban conurbations of the north and midlands, plus South Wales and central Scotland. The two major clusters of high average spending (Southwest of England and Southwest parts of London) expanded substantially during the short campaign (Figure 7), and was joined by another in the Southeast: there were clusters of below-average spending then in the same urbanindustrial areas.

\section{Insert Figures 8-9}

Finally, the maps for Labour are to a considerable extent a mirror image of those for its opponents. Labour spent relatively little on the long campaign (Johnston et al., 2011, 2012) and there were no clusters of seats where it spent above-average levels (Figure 8) outside London, where clusters of high spending were evident in the central southern parts of London (the Croydon seats and incorporating Putney and Battersea), but also in the north of the capital, from Westminster North to seats near Finchley and around Enfield. There were, however, large tracts of the country in the low-low quadrant, which correspond mainly to areas where the other two parties spent relatively large amounts on their campaigns. The latter feature was accentuated in the short campaign, notably across much of southern England, but there were also clusters of constituencies with above average spending, mainly in the English urban areas (though not also those in Wales and Scotland) where the Conservatives and Liberal Democrats spent relatively little (Figure 9). London again proved an exception with clusters of high average spending in the Central parts, across constituencies moving eastwards from the centre and Northwest near Ealing and Harrow. 


\section{Regression Analysis}

The exploratory evidence presented in both the Moran's I scatter plots and the LISA cluster maps suggests geographical elements to both party vote share and spending patterns in Britain at the 2010 general election. Are the two related: did each party perform better in those clusters of seats where it spent more? In addition, were there any spillover effects for the spending? Did a party perform better - all other factors having been taken into consideration - in constituencies where it spent more on the two campaigns in neighbouring constituencies and, complementing that question, did it perform less well in seats where its opponents spent above average amounts not only there but also in their neighbouring constituencies? In this section we report on a series of regression models to address these questions. First, we estimate an OLS model for each of the three main parties to examine the effects of the party activism during the long and the short campaign on party support. Second, we run similar models but explicitly test for spatial autocorrelation in the spending variables to explore whether there were spillover effects; this is done by augmenting the model to include compound variables corresponding to the six short and long party spending variables that have been multiplied by the queen contiguity weight matrix. Finally, following statistical evidence that the errors of these OLS regressions with spatially lagged spending variables are spatially autocorrelated (i.e. in the dependent variable) we re-estimate the second set of regressions using a spatial error modelling technique.

\section{The general pattern}

The first set of OLS models includes the traditional socio-economic variables as well as party spending variables for the short and long campaign. ${ }^{10}$ The results are in Table 1 which includes a number of model diagnostic tools $\left(\mathrm{R}^{2}\right.$, AIC, Log Likelihood etc) to assess the improvement in fit during the modelling stages.

The $\mathrm{R}^{2}$ values indicate that the explanatory variables account for a large proportion in the variation in 2010 vote shares for all three parties. As expected, the social cleavage variables are more important influences on the pattern of support for the Conservatives and Labour than the Liberal Democrats. Conservative support was most evident in those constituencies which contained a large number of people with degrees and those that owned their own home while Labour tended to perform best in more deprived areas, particularly in constituencies with fewer owner-occupiers. Labour also performed well in constituencies with large numbers of people working in education, indicative of its support among public sector workers in general (Curtice et al., 2010). But large numbers of students in a constituency were associated with low levels of Labour support, probably reflecting discontent with Labour's policy to increase tuition fees (opposed by the Liberal Democrats, who polled strongly in university towns). The relative number of students in a constituency was the only coefficient among the eight census variables that was statistically significant in the

\footnotetext{
${ }^{10}$ To undertake this task we employ the GeoDa open source software. This software was developed at the Spatial Analysis Lab at the University of Illinois and can be downloaded for free from: https://www.geoda.uiuc.edu/
} 
analysis for that party, further evidence that the Liberal Democrats lacked a coherent socio-economic support base.

\author{
Insert Table 1
}

Turning to the effects of place-based campaigning in the months preceding the election and during the 'official' campaign (the short and long campaigns in Table 1), significant and positive regression coefficients for all parties show that spending on each of the campaigns was significantly related to their 2010 vote share. Spending on the long campaign has not been analysed for previous elections, but the results here show that it mattered for all three parties. Where they committed resources and were active in the months preceding the 'official' campaign, their local candidates improved their performance; indeed it was particularly important for the Liberal Democrats (coefficient 0.31). This provides further evidence that grassroots activism before the 'official' campaign - where parties socialise their vote before the mobilising phase of the campaign in the last weeks before the election - is not only vital for local parties but also highly effective (Cutts et al., 2012). The Liberal Democrats are adept at targeted intensive grassroots campaigning, not only at election time but all year round, to enhance their performance in general elections (Cutts, 2006); they spent relatively little in many seats on the 2010 long campaign (Figure 4), but where they did, it had a substantial impact.

As well as having a positive impact on its own performance, each party's campaign spending also had a negative impact on its rivals' vote shares (with two exceptions: Conservative long and short campaign spending on Liberal Democrat vote share). Thus the more the Liberal Democrats spent on the long campaign the worse the Conservatives and Labour did; the comparable impact of short campaign spending was also significant but less substantial. This suggests that continuous or sustained prior interaction with voters not only brought the Liberal Democrats electoral benefits but also had a substantial effect on both the other parties' electoral performance. The Conservatives spent much more than the other two parties on the long campaign, especially in seats where it was targeting Labour incumbents, and this also brought dividends - although the relative size of the two coefficients suggests that its short campaign spending had a greater impact on Labour's vote share.

\title{
Spatial Autocorrelation of Party Spending Variables
}

To identify whether there were any spillover effects of a party's spending on its and its opponents' performance in neighbouring constituencies Table 2 reports a further set of models in which the compound spatial lag spending variables have been added to the same explanatory variables as in the previous models. These three models, therefore, explicitly test the impact of socio-economic explanatory variables and party spending variables on party vote share along with the spatial autocorrelation of each party spending variable from both campaign periods. 
Insert Table 2

For all three parties, the inclusion of these compound spending variables led to an improvement in fit $\left(\mathrm{R}^{2}\right)$ and a reduction in the log-likelihood test. In both the Labour and Conservative regression models, some of the socio-economic explanatory variables became insignificant following the inclusion of the compound variables. The coefficients for the party spending variables also reduced in magnitude but remained significant in the direction specified in Table 1; for the Liberal Democrats these indicate that the non-compound variables remained at a similar magnitude and statistical significance. The only slight difference from the previous models was the significant small negative effect of the Conservative long campaign on Liberal Democrat support. Of the three parties, the Liberal Democrats were still the party to benefit most from intensive local campaigning in the constituency itself.

The coefficients for the compound variables indicate, first, that the more all three parties spent on campaigning in constituencies adjacent to constituency $i$ the more votes they got in constituency $i$, for both campaign periods. For all three parties, therefore, campaigning in constituencies is not spatially independent. Second, during the long campaign period each party benefited from the spillover effects of its own campaigning. Third, of the three main parties, the more the Conservatives spent on the short campaign in constituencies adjacent to constituency $i$ the more votes they got in constituency $i$. Labour also benefited from such spillover effects but to a smaller extent (a coefficient of 0.15 compared to 0.22 for the Conservatives); each party's spending also had a similar negative impact on its opponent's performance (negative coefficients of -0.16 and -0.18 respectively). Where the Liberal Democrats were active during the short campaign in seats adjacent to constituency $i$, the party significantly increased support in this constituency but without any significant negative impact on either of its opponents' performance.

\section{A spatial error model}

While the regressions in Table 2 explicitly take account of spillover effects through the inclusion of lagged spending variables, they don't also take account of whether the spatial heterogeneity of the dependent variables has a direct effect on vote shares whether its performance in one constituency was related to its performance in adjacent seats. The exploratory evidence presented earlier clearly suggested the presence of a geographical clustering to party vote shares. Given this, the regressions were re-estimated using the correct functional form with such spatial autocorrelation in the dependent variable explicitly incorporated. Two types of regression model - the spatial lag model ${ }^{11}$ and the spatial error model - are typically used to determine the influence of such spatial relationships (Neumayer and Plumper 2012). Here we

\footnotetext{
${ }^{11}$ The spatial lag model takes account of spatial dependence by adding a spatially lagged dependent variable on the right hand side of the regression equation. It is appropriate when we expect that the values of $y$ in one unit are influenced by the values of $y$ found in $i$ 's neighbours.
} 
examined the model diagnostics of the previous models and found that the spatial dependence for all three parties entered through the errors rather than through a systematic component of the model. ${ }^{12}$ Given that the errors of the OLS regressions in Table 2 were spatially correlated, the regressions were re-estimated using a spatial error model. The results are shown in Table 3.

\section{Insert Table 3}

A coefficient on the spatial errors (lambda) is included as an additional indicator. It is positive and highly significant for all three parties and as a result the general model fits improved. The model diagnostics suggest that far more of the variation in Conservative and Labour vote shares was explained after taking account of spatially correlated errors. But while there are significant increases in the $\mathrm{R}^{2}$ for these two parties, there is only a slight improvement in the Liberal Democrat model. This is confirmed by the magnitude of changes in log-likelihood and AIC values, which is greatest for the Conservative party and smallest for the Liberal Democrats, with the low value for the latter probably reflecting concentration of this party's vote share in the South West. Nonetheless, the inclusion of space considerably improves the predictive power of the model for each political party. ${ }^{13}$

Once we re-estimate the models using spatial regression techniques, it is clear that the importance of socioeconomic explanations on Labour and Conservative party support had been understated in Table 2. In 2010, the Conservatives secured more support in affluent and rural constituencies which contained large numbers of retired people and homeowners. By contrast, the Labour vote was higher in their manufacturing heartlands and those seats with a large Muslim population. The Liberal Democrat model remained fairly stable. The only noticeable difference was the decline in support in seats as the number of Muslims increased, suggesting that the Muslim 'protest vote' against Labour in 2005 wasn't repeated five years later. The size, direction and significance of the non-compound spending variables for all three parties across both campaign periods remained largely unchanged. There was also little change in the lagged spending variables. Using the spatial error modelling technique did marginally affect the size of the Labour and Conservative lagged spending coefficients during the short campaign but the significance of these variables remained strong and in the direction previously stated.

\footnotetext{
${ }^{12}$ In spatial econometrics, tests based on the Lagrange Multiplier provide an indication of the spatial processes that cause autocorrelation. For all three parties, the diagnostics for spatial dependence for the weight matrix indicated that a spatial error model was more appropriate than a spatial lag. The Lagrange Multiplier Error was 17.54* (Liberal Democrats), 237.95* (Conservatives) and 173.43* (Labour). These figures were much higher than the equivalent lag diagnostics and were significant at the $99 \%$ level.

${ }^{13}$ While space is an important driver of party vote shares, the Breusch-Pagan test statistic suggests that there is still heteroskedasticity in the models even after introducing the spatial error terms. In each regression, the likelihood ratio tests of spatial error dependence indicate that the spatial effects models are improvements over the preceding OLS models but it didn't make the spatial effects entirely disappear.
} 


\section{The Impact of Spending}

Figures $10 \mathrm{a}-10 \mathrm{c}$ present the profiles of the impacts of long campaign spending in constituency $i$, the spillover effects onto constituencies $i$ from campaign spending in its contiguous constituencies, and the effect of these two combined, estimated respectively from the regressions in table 3 . In each case, the values of all variables except that being considered (i.e. spending by each party) are held constant at their means while that of the one under consideration is varied to evaluate its impact, ceteris paribus, on the dependent variable.

\section{Insert Figure 10a-10c}

This evidence presented in Figure 10a corroborates the belief that the effect of long campaign spending in constituency $i$ on vote share varies between the parties. Although all three parties experience an increase in vote share due to campaign spending, the Liberal Democrats benefit the most and the Conservatives benefit the least. Under the fitted model and as illustrated through the slopes of the lines, an increase in campaign spending of 1 percentage point increases the vote shares of the Liberal Democrats, Labour and Conservatives by $0.3,0.19$ and 0.1 percentage points, respectively.

The spillover effects on constituency $i$ 's vote share of long campaign spending in constituency $i$ 's contiguous constituencies also vary between parties, as shown in Figure 10b. As one might expect, these effects on vote share are smaller than the effects of campaign spending on one's own constituency detailed previously, but they remain both statistically significant and substantial. Under the fitted model, an increase in campaign spending of 1 percentage point in constituency $i$ 's contiguous constituencies increases Liberal Democrat, Labour and Conservative vote shares by $0.08,0.08$ and 0.11 percentage points respectively. However, the fact that the differences between these slope coefficients are statistically insignificant misses the point. If the Liberal Democrats were to increase their campaign spending in constituency $i$ 's contiguous constituencies by 20 percentage points (say, from 0 per cent to 20 per cent) then they would experience an increase in vote share of 1.6 percentage points; this represents a 9.6 percent increase in their vote share from 16.7 to 18.3 percentage points. A increase in Conservative campaign spending in constituency $i$ 's contiguous constituencies by 20 percentage points (again from 0 per cent to 20 per cent) would also result in an increase in vote share of 1.6 percentage points from 28.6 to 30.2 percentage points, but this represents a smaller increase in their overall vote share of 5.6 percent. Hence, in relative terms, the effects on constituency $i$ 's vote share of long campaign spending in neighbouring constituencies are much more important for the Liberal Democrats than for the other two parties. ${ }^{14}$

\footnotetext{
${ }^{14}$ Note that the campaign spending in constituency $i$ 's contiguous constituencies ranges between 0 and 77 percent. Therefore we restrict our profile to a limit of 80 percent to avoid predictions that are out of bounds.
} 
Figure 10c shows these two effects combined. It illustrates that, for example, if the Liberal Democrats had been able to push their long campaign expenditure up uniformly in all seats by enough to shift their average long campaign $\%$ spending up by $250 \%$, from $1 \%$ to $42 \%$, and if all other variables - including the other parties' spending - had been held at their national averages, then the Liberal Democrats would have gained more votes nationally than either of the other two main parties. ${ }^{15}$

\section{Insert Figure 11}

Figure 11 shows the comparable profiles for these two effects combined but this time when applied to the short campaign. The profiles have a high degree of similarity, with slopes at $0.28,0.275$ and 0.267 for the Labour, Conservatives and Liberal Democrats parties respectively; as the initial values (intercepts) are very similar it also illustrates the effects of short campaign spending patterns are similar across the three parties.

\section{Conclusion}

Targeted campaign messages are an integral part of the post-modern election campaign. At the national level, parties strategically control how their leader, candidates and policies are presented in the 24 hour news media to get their message across to target voters. Locally, often with assistance from outside the constituency, the party focuses efforts on key marginal seats with attempts to target voters both prior to and during the election campaign. In the years preceding the general election, local parties work hard to socialise voters, promote the candidate and maintain a visible presence. Come election time, as constituency party activism reaches its peak, parties seek to mobilise their own vote and capture those undecided electors who can make the difference between winning and losing. This is borne out by our findings here. Local constituency electioneering during both campaign periods have a significant effect on party support. Moreover, constituencies are not spatially independent, with campaign spillover effects influencing party performance in nearby constituencies in both campaign periods. Although many studies suggest that spatial factors might be influencing party vote shares, few continue to take explicit account of spatial factors in their empirical analyses. Apart from failing to acknowledge possible spillover effects, ignoring spatial effects can lead to biased results, with the determinants of party vote share, particularly for Labour and the Conservatives, being either over- or under-stated when space is omitted from the regression analysis.

For Labour and the Conservatives, geography (local context) has an important influence along with other more established drivers of party support. The Conservatives in particular benefited from campaign spillover effects in 2010, not only improving their own support in nearby seats, but restricting Labour. However, our findings suggest that intensive grassroots campaigning is particularly salient to the electoral fortunes of the Liberal Democrats. Whilst this finding is not entirely surprising, of particular interest is that intensive Liberal Democrat campaigning

\footnotetext{
${ }^{15}$ The three party lines shown are constructed separately (values of other parties' spending are held constant at their means) and then for brevity are shown together in Figure 10c.
} 
proved more effective in the months preceding the 'official' election period than in the three week election campaign itself. Not only did it boost the Liberal Democrats' own support, but it had a significant negative impact on both Labour and Conservative vote share. In addition, the spatial autocorrelation analyses reported above show that all parties, but particularly the Liberal Democrats, also gained more votes in a constituency when they campaigned hard in surrounding seats than when they did not. During both campaign periods, but particularly in the long campaign', spillover effects significantly influenced Liberal Democrat party performance in nearby constituencies. This represents an important substantive finding which builds on findings from analyses of local elections (Dorling, Rallings and Thrasher, 1998; Cutts, 2006a) and at the previous general election during the 'official' campaign period (Cutts and Webber, 2010).

Part of the explanation lies in the Liberal Democrats' use of grassroots campaigning outside the election period to maintain a visible local presence (Cutts, 2006a). Between general elections, winning council seats and running local councils is used to gain greater electoral credibility and provide a platform for parliamentary success (Ashdown, 2010). The Liberal Democrats also use grassroots campaigning to recruit local activists and party workers which cements the local party infrastructure and enables the party to be more effective in targeting local resources. Therefore, maintaining a visible campaign presence not just at election times but from one election to the next not only aids the promotion of the local Liberal Democrat parliamentary candidate but also provides the resources to socialise their vote well in advance of the general election. The combination of traditional and modern campaign methods and a visible presence on the ground also enhances the party's performance in neighbouring constituencies.

Party spending in the long campaign period is, therefore, likely to be a good measure of campaign intensity during that pre-election period. With fewer resources than the other main parties, the Liberal Democrats are only going to spend large amounts in those seats which had sustained activism throughout the electoral cycle. Of course, such findings were evident for the Liberal Democrats in the 2010 general election. Now in coalition government with the Conservatives, it remains to be seen whether the party can sustain the level of campaign activism over the electoral cycle in the face of large scale losses to its local base. The party will need to adapt its grassroots campaigning, local tactics and strategy to reflect the fact that the party is no longer in opposition if it is going to reap similar electoral rewards and positive spillover effects in the next general election, and not return to pre 1997 levels of parliamentary representation.

More generally, this paper goes beyond reinforcing the received wisdom on local electioneering. It is not only one of the few papers to examine spillover effects in local campaigns in Britain, but the first to apply to the long as well as the short campaign. It stresses that future empirical analyses of voting at the constituency scale must explicitly take account of spatial heterogeneity in order to correctly gauge the magnitude and significance of factors that affect parties' parliamentary performance.

\section{Bibliography}


Agnew, J. (1987). Place and Politics: The Geographical Mediation of State and Society. Boston: Allen and Unwin.

Andersen R and Heath A (2002) Class matters: The persisting effects of contextual social class on individual voting in Britain, 1964-97, European Sociological Review 18, 125-38

Anselin L (1996) The Moran scatterplot as an ESDA tool to assess local instability in spatial association, in Fisher M, Scholten H and Unwin D (Eds.) Spatial analytical perspectives on GIS, 111-125, Taylor and Francis, London

Anselin, L. (2001). Spatial econometrics. In B. Baltagi (Ed.), Companion to econometrics, Oxford: Basil Blackwell

Ashcroft, M. A. (2010) Minority Verdict: the Conservative Party, the Voters and the 2010 Election (London: Biteback Books).

Ashdown, P. (2010) A Fortunate Life: the Autobiography of Paddy Ashdown. London: Aurum.

Books, J, and Prysby, C. (1991) Political Behaviour and the Local Context. New York: Praeger.

Books, J, and Prysby. C. 1999. "Contextual Effects on Retrospective Economic Evaluation: The Impact of the State and Local Economy." Political Behaviour 21(1): 1-16.

Butler D and Stokes D (1969) Political Change in Britain, $I^{\text {st }}$ Edition, Basingstoke: Palgrave Macmillan

Butler D and Stokes D (1974) Political Change in Britain, $2^{\text {nd }}$ Edition, Basingstoke: Palgrave Macmillan

Cox K (1969) The voting decision in a spatial context. Progress in Geography 1, 81117.

Crewe I and Payne C (1971) Analysing the census data. In Butler D and PintoDuschinsky M (Eds.), The British general election of 1970, Macmillan, London, 416-36

Curtice J (1996) Who votes for the centre now, in MacIver D (Ed), The Liberal Democrats, London, Harvester Wheatsheaf, 191-204

Curtice, J., Fisher, S. and Ford, R. (2010) An analysis of the results. In D. Kavanagh and P. Cowley, The British General Election of 2010, Basingstoke: Palgrave Macmillan, 385-426. 
Cutts, D. (2012) Yet Another False Dawn? An examination of the Liberal Democrats' Performance in the 2010 General Election, British Journal of Politics and International Relations, Vol 14(1): 96-114

Cutts D (2006a) Continuous campaigning and electoral outcomes: The Liberal Democrats in Bath, Political Geography 25, 72-88

Cutts D. (2006b) Where we work we win: A case study of Local Liberal Democrat campaigning, Journal of Elections, Public Opinion and Parties 16(3), 221-41

Cutts, D. and Webber, D. (2010) Voting Patterns, Party Spending and Relative Location in England and Wales, Regional Studies, Vol 44, Issue 6: 735-60

Cutts, D. and Fieldhouse, E. (2009) What Small Spatial Scales are Relevant as Electoral Contexts for Individual Voters? The Importance of the Household on Turnout at the 2001 General Election, American Journal of Political Science Vol 53, Issue 3: 726-39

Cutts, D., Johnston, R., Pattie, C., and Fisher, J. (2012) Laying the foundations for electoral success: Conservative pre-campaign canvassing before the $2010 \mathrm{UK}$ general election, Journal of Elections, Public Opinion and Parties (forthcoming)

Denver D and Hands G (1997) Modern constituency electioneering: Local campaigning in the 1992 general election, Frank Cass, London

Dorling D, Rallings C and Thrasher M (1998) The Epidemiology of the Liberal Democrat Vote, Political Geography, 17, 1, 45-70

Dunleavey P (1979) The urban basis of political alignment, British Journal of Political Science 9, 409-43

Fieldhouse E and Cutts D (2008) The effectiveness of local party campaigns in 2005: combining evidence from campaign spending, agent survey data and individual level data, British Journal of Political Science, Vol 39 (1): 367-88

Fieldhouse E, Cutts D and Russell A (2006) Neither north nor south: The Liberal Democrat performance in the 2005 general election, Journal of Elections, Public Opinion and Parties 16(1): 77-92

Fisher, J. and Denver, D (2008) 'From Foot-Slogging to Call Centres and Direct Mail: A Framework for Analysing the Development of District-Level Campaigning'. European Journal of Political Research 47:794-826

Fisher, J., Denver, D., \& Hands, G. (2006), 'The Relative Electoral Impact of Central Party Co-ordination and Size of Party Membership at Constituency Level' Electoral Studies.25: 664-76. 
Fisher, J., Cutts, D. and Fieldhouse, E. (2011) The Electoral Effectiveness of Constituency Campaigning in the 2010 British General Election: The 'Triumph' of Labour? Electoral Studies, Vol 30(4): 816-28

Huckfeldt, R, and Sprague, J. (1995) Citizens, Politics and Social Communication: Information and Influence in an Election Campaign. Cambridge: Cambridge University Press.

Irwin E and Bockstael N. (2004) Endogenous spatial externalities: Empirical evidence and implications for the evolution of exurban residential land use patterns. In Anselin L, Florax R and Rey S (Eds.) Advances in spatial econometrics: Methodology, tools and applications, 359-380, Springer, Berlin

Jacobson G (1990) The effects of campaign spending in house elections: New evidence for old arguments, American Journal of Political Science 34, 334-62

Johnston R and Pattie C (1995) The impact of party spending on party constituency campaigns at recent British general elections, Party Politics 1, 261-74

Johnston R and Pattie C (1997) The region is not dead: Long live the region. Personal evaluations and voting at the 1992 British General Election, Space and Polity 1, 103-13

Johnston R and Pattie C (1998) Composition and context: Region and voting in Britain revisited during Labour's 1990s' revival, Geoforum 29, 309-29

Johnston R and Pattie C (2006) Putting voters in their place: geography and elections in Great Britain, Oxford University Press, Oxford

Johnston R and Pattie C (2008) Money and votes: a New Zealand example. Political Geography 27, 113-133.

Johnston R and Pattie C (2010) The local campaigns and the outcome. In N. Allen and J. Bartle, editors, Britain at the Polls 2010. London: Sage Publications, 203-239.

Johnston R, Pattie C and Allsopp J (1988) A nation dividing? The electoral map of Great Britain 1979-87, Longman, London

Johnston R, Pattie C, Dorling D, Rossiter D, Tunstall H and Macallister I (1998) New Labour landslide - Same old electoral geography?, in Denver D, Fisher J, Cowley P and Patttie C (Eds.), British Elections and Parties Review 8, Frank Cass London, 35-64

Johnston, R., Pattie, C., Cutts, D., Fieldhouse, E. and Fisher, J. (2011) Local Campaign Spending at the 2010 General Election and its Impact: Exploring what Wider Regulation has Revealed, Political Quarterly, Vol 82 (2): 169-92 
Johnston, R., Pattie, C., Cutts, D. and Fisher, J. (2012) Spending, Contacting and Voting: The 2010 General Election in the Constituencies, Environment and Planning A (forthcoming)

Johnston R, Jones K, Sarker R, Propper C, Burgess S and Bolster A (2004) Party support and the neighbourhood effect: Spatial polarisation of the British electorate 1991-2001, Political Geography 23, 367-402

Johnston R, Propper C, Burgess S, Sarker R, Bolster A and Jones K (2005) Spatial scale and the neighbourhood effect: Multinomial models of voting at two recent British general elections, British Journal of Political Science 35, 487514

Johnston R, Jones K, Propper C and Burgess S (2007) Region, constituency, neighbourhood and/or home: Local contexts and voting at the 1997 general election in England, American Journal of Political Science 51, 640-654

Mcallister I and Studlar D (1992) Region and voting in Britain: Territorial polarization or artefact?, American Journal of Political Science 376, 168-99

Miller W (1977) Electoral dynamics in Britain since 1918, Palgrave Macmillan, Basingstoke

Miller W (1978) Social class and party choice in England: A new analysis, British Journal of Political Science 8, 259-284

Neumayer, E. and Plumper, T. (2012) Conditional Spatial Policy Dependence: Theory and Model Specification, Comparative Political Studies, 45(7) 819-49

Pattie, C. J. and Johnston, R. J., 2009, Still talking, but is anyone listening? The changing face of constituency campaigning in Britain, 1997-2005, Party Politics, 15(4), 411-34

Pattie, C., and Johnston, R. (2000) "People Who Talk Together Vote Together: An Exploration of Contextual Effects in Great Britain." Annals of the Association of American Geographers 90(1): 41-66.

Pattie C, Johnston R and Fieldhouse E (1995) Winning the local vote: The effectiveness of constituency campaign spending in Great Britain, 1983-92, American Political Science Review 89, 963-83

Rodgers E (1962) Diffusion of Innovation, The Free Press, New York

Russell A and Fieldhouse E (2005) Neither left nor right? The Liberal Democrats and the electorate, Manchester University Press, Manchester

Taylor, P, and Johnston, R (1979). Geography of Elections. London: Penguin Books. 
Voss P, Long D, Hammer R and Friedman S (2006) County child poverty rates in the US: A spatial regression approach, Population Research Policy Review 25, 369-391

Whiteley P and Seyd P (1994) Local party campaigning and voting behaviour in Britain, Journal of Politics 56, 242-51

Wrigley N, Holt T, Steel D and Tranmer M (1996) Analysing, modelling and resolving the ecological fallacy, in Longley $\mathrm{P}$ and Batty M (Eds.) Spatial analysis: Modelling in a GIS environment, GeoInformation International, Cambridge, England, 23-40 
Table 1. OLS Model of Short and Long Campaign Spending on 2010 Party Vote Shares (controlling for Socio-Economic characteristics of the Constituency)

\begin{tabular}{|c|c|c|c|}
\hline Political Party & Labour & Conservatives & $\begin{array}{c}\text { Liberal } \\
\text { Democrats }\end{array}$ \\
\hline Constant & $\begin{array}{l}65.60 * * \\
(3.75) \\
\end{array}$ & $\begin{array}{l}-0.14 \\
(4.25) \\
\end{array}$ & $\begin{array}{l}13.68 * * \\
(2.78)\end{array}$ \\
\hline$\%$ Degree & $\begin{array}{l}-0.29 * * \\
(0.06)\end{array}$ & $\begin{array}{l}0.40 * * \\
(0.07)\end{array}$ & $\begin{array}{c}0.04 \\
(0.04)\end{array}$ \\
\hline$\%$ Manufacturing & $\begin{array}{l}0.21 * * \\
(0.07)\end{array}$ & $\begin{array}{l}-0.07 \\
(0.08)\end{array}$ & $\begin{array}{l}-0.03 \\
(0.05)\end{array}$ \\
\hline$\%$ Agriculture & $\begin{array}{l}-1.32 * * \\
(0.20)\end{array}$ & $\begin{array}{c}0.18 \\
(0.23)\end{array}$ & $\begin{array}{c}0.10 \\
(0.15)\end{array}$ \\
\hline$\%$ Home Owners & $\begin{array}{l}-0.50 * * \\
(0.04)\end{array}$ & $\begin{array}{l}0.52 * * \\
(0.05)\end{array}$ & $\begin{array}{c}0.03 \\
(0.03)\end{array}$ \\
\hline$\%$ Pensioners & $\begin{array}{r}0.07 \\
(0.17)\end{array}$ & $\begin{array}{l}-0.02 \\
(0.20)\end{array}$ & $\begin{array}{c}0.04 \\
(0.13)\end{array}$ \\
\hline$\%$ Muslim & $\begin{array}{r}0.11 \\
(0.07)\end{array}$ & $\begin{array}{c}0.02 \\
(0.08)\end{array}$ & $\begin{array}{l}-0.08 \\
(0.05)\end{array}$ \\
\hline$\%$ Students & $\begin{array}{l}-0.36 * * \\
(0.14)\end{array}$ & $\begin{array}{c}0.13 \\
(0.16)\end{array}$ & $\begin{array}{l}\mathbf{0 . 2 3 *} \\
(0.10)\end{array}$ \\
\hline$\%$ Working in Education & $\begin{array}{l}0.74 * * \\
(0.24)\end{array}$ & $\begin{array}{c}-1.08 * * \\
(0.29)\end{array}$ & $\begin{array}{l}\mathbf{0 . 3 8 *} \\
(0.19)\end{array}$ \\
\hline Lib Dem Long Campaign Spending & $\begin{array}{l}-0.15 * * \\
(0.01)\end{array}$ & $\begin{array}{l}-0.12 * * \\
(0.01)\end{array}$ & $\begin{array}{l}0.31 * * \\
(0.01)\end{array}$ \\
\hline Labour Long Campaign Spending & $\begin{array}{l}0.22 * * \\
(0.01)\end{array}$ & $\begin{array}{l}-0.10 * * \\
(0.01)\end{array}$ & $\begin{array}{l}-0.11 * * \\
(0.01)\end{array}$ \\
\hline Conservatives Long Campaign Spending & $\begin{array}{l}-0.08 * * \\
(0.01)\end{array}$ & $\begin{array}{l}0.15 * * \\
(0.01)\end{array}$ & $\begin{array}{l}-0.01 \\
(0.01)\end{array}$ \\
\hline $\begin{array}{l}\text { Lib Dem Short Campaign } \\
\text { Spending (Orthogonal) }\end{array}$ & $\begin{array}{l}-0.07 * * \\
(0.01)\end{array}$ & $\begin{array}{l}-0.04 * \\
(0.01)\end{array}$ & $\begin{array}{l}0.15 * * \\
(0.01)\end{array}$ \\
\hline $\begin{array}{l}\text { Labour Short Campaign } \\
\text { Spending (Orthogonal) }\end{array}$ & $\begin{array}{l}0.21 * * \\
(0.01)\end{array}$ & $\begin{array}{l}-0.14 * * \\
(0.01)\end{array}$ & $\begin{array}{c}-0.08 * * \\
(0.01)\end{array}$ \\
\hline $\begin{array}{l}\text { Conservatives Short Campaign } \\
\text { Spending (Orthogonal) }\end{array}$ & $\begin{array}{l}-0.14 * * \\
(0.01)\end{array}$ & $\begin{array}{l}0.21 * * \\
(0.01)\end{array}$ & $\begin{array}{c}0.01 \\
(0.01)\end{array}$ \\
\hline Moran's I (residuals) & $0.36^{* * *}$ & $0.42 * *$ & $0.14 * *$ \\
\hline F-Statistic (prob.) & $172.71 * *$ & $98.09 * *$ & $126.55 * *$ \\
\hline Log Likelihood & -2142.57 & -2221.82 & -1952.94 \\
\hline Adjusted $\mathrm{R}^{2}$ & 0.79 & 0.68 & 0.74 \\
\hline $\mathrm{AIC}$ & 4315.13 & 4473.64 & 3935.88 \\
\hline
\end{tabular}


Table 2. Spatial Model of Party Spending on 2010 Party Vote Shares

\begin{tabular}{|c|c|c|c|}
\hline Political Party & 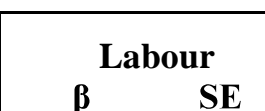 & \begin{tabular}{|c|}
\multicolumn{2}{c}{ Conservatives } \\
$\beta$
\end{tabular} & $\begin{array}{c}\text { Liberal } \\
\text { Democrats }\end{array}$ \\
\hline Constant & $64.03 * *(3.35)$ & \begin{tabular}{|l|l|}
-0.67 & $(3.88)$ \\
\end{tabular} & $\begin{array}{cc}\boldsymbol{\beta} & \mathrm{SE} \\
1.58 * *(2.78)\end{array}$ \\
\hline$\%$ Degree & $\begin{array}{|ll|}-0.32 * * & (0.06) \\
\end{array}$ & $0.39 * *(0.06)$ & $-0.01 \quad(0.05)$ \\
\hline$\%$ Manufacturing & $\begin{array}{|ll|}0.18 * * & (0.06) \\
\end{array}$ & $-0.05 \quad(0.07)$ & $(0.05)$ \\
\hline$\%$ Agriculture & \begin{tabular}{|ll}
$-0.82 * *$ & $(0.18)$ \\
\end{tabular} & $-0.14 \quad(0.21)$ & $(0.15)$ \\
\hline \% Home Owners & $\begin{array}{|ll|}-0.37 * * * & (0.04) \\
\end{array}$ & $0.40 * *(0.04)$ & $(0.03)$ \\
\hline$\%$ Pensioners & $(0.16)$ & $\begin{array}{ll}0.32 & (0.18)\end{array}$ & $(0.13)$ \\
\hline$\%$ Muslim & $(0.06)$ & $0.03 \quad(0.07)$ & $-0.08 \quad(0.05)$ \\
\hline$\%$ Students & $(0.12)$ & \begin{tabular}{|ll}
-0.07 & $(0.14)$
\end{tabular} & $0.25 *(0.10)$ \\
\hline$\%$ Working in Education & $(0.23)$ & \begin{tabular}{|ll}
-0.47 & $(0.26)$ \\
\end{tabular} & $0.47 *(0.19)$ \\
\hline Lib Dem Long Campaign Spending & $\begin{array}{|ll|}-0.13 * * & (0.01) \\
\end{array}$ & $-0.12 * *(0.01)$ & $0.30 * *(\mathbf{0 . 0 1})$ \\
\hline Labour Long Campaign Spending & $\begin{array}{|ll|}0.19 * * *(0.01) \\
\end{array}$ & $-0.08 * *(0.02)$ & $-0.10 * *(0.01)$ \\
\hline Cons Long Campaign Spending & $\begin{array}{|ll|}-0.04 * * & (0.01) \\
\end{array}$ & $0.10 * *(0.01)$ & $-0.02 *(0.01)$ \\
\hline $\begin{array}{l}\text { Lib Dem Short Campaign } \\
\text { Spending (Orthogonal) }\end{array}$ & $-0.06 * * \quad(0.01)$ & $-0.04 * *(0.01)$ & $0.14 * *(0.01)$ \\
\hline $\begin{array}{l}\text { Labour Short Campaign } \\
\text { Spending (Orthogonal) }\end{array}$ & $0.16 * * \quad(0.01)$ & $-0.09 * *(0.01)$ & $-0.07 * *(0.01)$ \\
\hline $\begin{array}{l}\text { Conservatives Short Campaign } \\
\text { Spending (Orthogonal) }\end{array}$ & $-0.09 * * \quad(0.01)$ & $0.16 * *(0.01)$ & $-0.00 \quad(0.01)$ \\
\hline $\begin{array}{l}\text { Lib Dem Long Campaign Spending } \\
* \text { Queen weight matrix }\end{array}$ & $(0.03)$ & $-0.04 \quad(0.03)$ & $0.10 * *(0.02)$ \\
\hline $\begin{array}{l}\text { Labour Long Campaign Spending } \\
\text { *Queen weight matrix }\end{array}$ & $0.12 * * \quad(0.03)$ & $0.02 \quad(0.03)$ & $0.03 \quad(0.02)$ \\
\hline $\begin{array}{l}\text { Cons Long Campaign Spending } \\
* \text { Queen weight matrix }\end{array}$ & $-0.07 * * \quad(0.02)$ & $0.08 * *(0.03)$ & $-0.01 \quad(0.02)$ \\
\hline $\begin{array}{l}\text { Lib Dem Short Campaign Spending } \\
\text { (Orthogonal) *Queen weight matrix }\end{array}$ & $(0.02)$ & $-0.01 \quad(0.03)$ & $0.05 * \quad(0.02)$ \\
\hline $\begin{array}{l}\text { Labour Short Campaign Spending } \\
\text { (Orthogonal) *Queen weight matrix }\end{array}$ & $0.15 * * \quad(0.02)$ & $-0.16 * *(0.02)$ & $-0.02 \quad(0.02)$ \\
\hline $\begin{array}{l}\text { Cons Short Campaign Spending } \\
\text { (Orthogonal) *Queen weight matrix }\end{array}$ & $-0.18 * * \quad(0.02)$ & $0.22 *(0.03)$ & $0.03 \quad(0.02)$ \\
\hline Moran's I (residuals) & $0.33 * *$ & $0.39 * *$ & $0.11 * *$ \\
\hline Lagrange Multiplier Diagnostic & Spatial Error & Spatial Error & Spatial Error \\
\hline F-Statistic (prob.) & $170.07 * *$ & $95.74 * *$ & $95.41 * *$ \\
\hline Log Likelihood & -2051.25 & -2143.45 & -1933.04 \\
\hline Adjusted $\mathrm{R}^{2}$ & 0.85 & 0.76 & 0.76 \\
\hline AIC & 4144.50 & 4328.90 & 3908.07 \\
\hline
\end{tabular}

$* *<0.01 ; *<0.05$ 
Table 3. Spatial Model of 2010 Party Vote Shares (Party 'Long' and 'Short' Campaign Spatially Weighted; and Spatial Error)

\begin{tabular}{|c|c|c|c|}
\hline Political Party & $\beta \quad \begin{array}{rr}\text { Labour } \\
\beta\end{array}$ & $\begin{array}{c}\text { Conservatives } \\
\beta \quad \text { SE }\end{array}$ & $\begin{array}{l}\text { Liberal } \\
\text { Democrats }\end{array}$ \\
\hline Constant & 63.10** (3.32) & $-0.54 \quad(3.69)$ & $13.99 * *(2.89)$ \\
\hline$\%$ Degree & $-0.43 * * \quad(0.06)$ & $0.49 * *(0.07)$ & $\begin{array}{ll}-0.00 \quad(0.05) \\
\end{array}$ \\
\hline$\%$ Manufacturing & $\begin{array}{ll}0.20 & * * * \\
\end{array}$ & $\begin{array}{ll}-0.18 * & (0.08) \\
\end{array}$ & $(0.06)$ \\
\hline$\%$ Agriculture & $-1.38 * * \quad(0.19)$ & $0.85 * *(0.21)$ & $0.10 \quad(0.16)$ \\
\hline$\%$ Home Owners & $-0.30 * * \quad(0.04)$ & $0.34 * *(0.04)$ & 0.04 \\
\hline$\%$ Pensioners & $-0.48 * * \quad(0.15)$ & $0.67 * *(0.16)$ & -0.08 \\
\hline$\%$ Muslim & $0.26 * * \quad(0.06)$ & $-0.22 *(0.06)$ & $-0.12 *(0.05)$ \\
\hline \% Students & $-0.22 * * \quad(0.10)$ & $0.10 \quad(0.11)$ & $0.22 *(0.10)$ \\
\hline$\%$ Working in Education & $(0.23)$ & $-0.97 * *(0.26)$ & $0.50 *(0.20)$ \\
\hline Lib Dem Long Campaign Spending & $-0.12 * * \quad(0.01)$ & $-0.12 * *(0.01)$ & $0.30 * *(0.01)$ \\
\hline Labour Long Campaign Spending & 0.19** $\quad(\mathbf{0 . 0 1})$ & $-0.06 * *(0.01)$ & $-0.10 * *(0.01)$ \\
\hline Cons Long Campaign Spending & $-0.04 * * \quad(0.01)$ & $0.10 * *(0.01)$ & $-0.02 *(0.01)$ \\
\hline $\begin{array}{l}\text { Lib Dem Short Campaign } \\
\text { Spending (Orthogonal) }\end{array}$ & $-0.06 * * \quad(0.01)$ & $-0.04 * *(0.01)$ & $0.14 * *(0.01)$ \\
\hline $\begin{array}{l}\text { Labour Short Campaign } \\
\text { Spending (Orthogonal) }\end{array}$ & $0.14 * * \quad(0.01)$ & $-0.06 * *(0.01)$ & $-0.07 * *(0.01)$ \\
\hline $\begin{array}{l}\text { Conservatives Short Campaign } \\
\text { Spending (Orthogonal) }\end{array}$ & $-0.08 * * \quad(0.01)$ & $0.13 * *(0.01)$ & $-0.00 \quad(0.01)$ \\
\hline $\begin{array}{l}\text { Lib Dem Long Campaign Spending } \\
\text { *Queen weight matrix }\end{array}$ & $(0.03)$ & $-0.04 \quad(0.03)$ & $0.08 * *(0.02)$ \\
\hline $\begin{array}{l}\text { Labour Long Campaign Spending } \\
\text { *Queen weight matrix }\end{array}$ & $0.11 * * \quad(0.03)$ & $-0.02 \quad(0.04)$ & $0.01 \quad(0.03)$ \\
\hline $\begin{array}{l}\text { Cons Long Campaign Spending } \\
* \text { Queen weight matrix }\end{array}$ & $-0.07 * * \quad(0.02)$ & $0.08 * *(0.03)$ & $-0.00 \quad(0.02)$ \\
\hline $\begin{array}{l}\text { Lib Dem Short Campaign Spending } \\
\text { (Orthogonal) *Queen weight matrix }\end{array}$ & $(0.03)$ & $0.01 \quad(0.03)$ & $0.05 * \quad(0.02)$ \\
\hline $\begin{array}{l}\text { Labour Short Campaign Spending } \\
\text { (Orthogonal) *Queen weight matrix }\end{array}$ & $0.09 * * \quad(0.02)$ & $-0.09 * *(0.03)$ & $-0.00 \quad(0.02)$ \\
\hline $\begin{array}{l}\text { Cons Short Campaign } \begin{array}{c}\text { Spending } \\
\text { (Orthogonal) *Queen weight matrix }\end{array} \\
\end{array}$ & $-0.14 * * \quad(0.03)$ & $0.13 * *(0.03)$ & $0.03 \quad(0.02)$ \\
\hline Lambda & $0.67 * * \quad(0.04)$ & $\mathbf{0 . 7 3} * *(\mathbf{0 . 0 3})$ & $0.26 * *(0.06)$ \\
\hline Likelihood Ratio Test & $178.05 * *$ & $240.33 * *$ & $17.99 * *$ \\
\hline Log Likelihood & -1962.22 & -2023.29 & -1924.04 \\
\hline $\mathrm{R}^{2}$ & 0.90 & 0.86 & 0.77 \\
\hline AIC & 3966.45 & 4088.57 & 3890.08 \\
\hline
\end{tabular}

